\title{
Alexis Carrel (1873-1944): Pioneer of vascular surgery and organ transplantation
}

\author{
Jason Merchant ${ }^{1}$, MD, Siang Yong $\operatorname{Tan}^{2}$, MD, JD
}

The first duty of life is to live - to live as completely as possible to increase life for oneself and for others, to make it more elevated, more sweet, and more beautiful. - Alexis Carrel

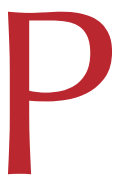

rior to the 1900s, to sever a major central blood vessel meant certain death, and to injure an artery in an extremity would mean an amputation. However, Alexis Carrel, a French-born physician-scientist and controversial historical figure, developed successful vascular suturing techniques that dramatically shifted the odds of life and limb salvage. Carrel later pursued organ transplantation with the first successful animal renal transplant. In recognition of "his work on vascular sutures and the transplantation of blood vessels and organs," Alexis Carrel, in 1912, was the first scientist in America to be awarded the Nobel Prize for Medicine.

\section{THE PATH TO AMERICA} Alexis Carrel, originally named Auguste, was born in Sainte-Foy-lès-Lyon, France, on 28 June 1873. Homeschooled for a number of years, he later attended

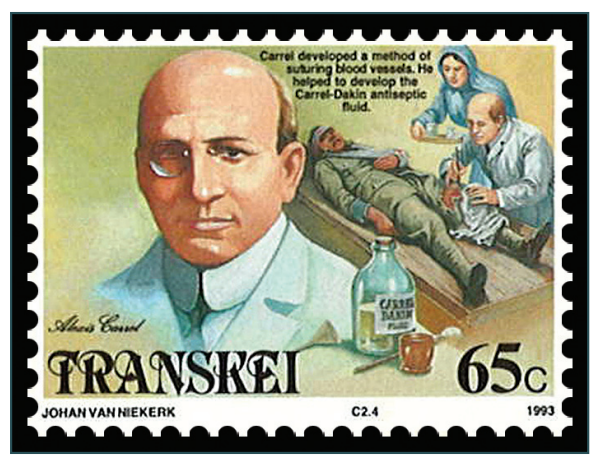

not working in wards, Carrel used his spare time to develop a method for suturing vessels, focusing on needle size and suture material. He then attempted to suture the external jugular vein to the carotid artery in a dog. The anastomosis was able to withstand the pressure generated by the arterial flow, and eventually, the vein hardened and took on an arterial pulse.

As Carrel refined his suturing techniques, he sought to improve the protocols for performing operations under sterile conditions, as he was bothered by high rates of infection. $\mathrm{He}$ also developed the triangulation method of small vessel anastomosis by first placing three sutures triangulated around the anastomosis site, which, via eversion of the anastomosis, helped to prevent thrombosis. With this method, surgeons could easily hold the ends of the vessels together without unnecessary handling using forceps, thus preventing bruising and swelling of the vessels. Soon, Carrel was able to remove segments of arteries in dogs and effectively replace them with venous grafts. He even managed to show that veins and arteries could, occasionally, be grafted between species. In the course of his vascular St Joseph School, where he received his Bachelor of Science degree in 1890. Drawn to physics and the natural sciences, Carrel pursued the medical profession, earning his Doctorate in 1900 from the University of Lyons. He subsequently performed his internship at various hospitals in Lyons. Carrel quickly became frustrated at the French medical establishment, which he believed frowned upon innovation, and left for Montreal, Canada. After Montreal, he moved on to the University of Chicago, Chicago, USA, and subsequently to the Rockefeller Institute for Medical Research in New York, USA.

VASCULAR WORK The assassination of French president Marie François Sadi Carnot had a major influence on Carrel's medical career. The president's stab wound resulted in a severed portal vein - a fatal injury during that period. Carrel lamented that there were no techniques available for repairing simple lacerations to blood vessels; prior attempts had resulted in clots, infection, or disruption of the anastomosis. When work, Carrel also pioneered methods of excorporeal tissue preservation, such as the use of a salt solution at freezing point. He studied various other solutions for storage, including glycerin, formalin and petroleum jelly, and used different treatment methods like hypothermia, heat and dehydration.

TRANSPLANTATION In addition to his work on vascular tissues, Carrel began experimenting with organ transplantation. In 1902, he transplanted a dog's kidney into its own neck. Although the transplanted kidney was able to produce urine immediately after the transplant, the dog died from infection a few days later. Carrel published these results in 1905; his report included his method of removing a patch of the aorta with the renal artery in order to avoid thrombosis in the small vessel anastomosis - a technique still used today. He successfully transplanted organs, including kidneys, ovaries and thyroid glands between different dogs. In an ambitious experiment, Carrel successfully amputated and then reattached

${ }^{1}$ Research carried out during 1st year residency, Transitional Residency Program, University of Hawaii, ${ }^{2}$ Emeritus Professor of Medicine, University of Hawaii, Honolulu, Hawaii, USA

Correspondence: Prof Tan Siang Yong, 2230 Liliha Street, Suite 104, Honolulu, HI 96817, USA. siang@hawaii.edu 
the hind leg of a dog by bringing together all blood vessels, muscles, bones and nerves. He, however, made no mention of the sensory and motor functions of the restored leg, or how long the dog survived. In addition to transplantation of organs and reattachment of limbs, Carrel also performed innovative procedures on the heart, such as mitral valvulotomy, valvuloplasty, and coronary artery grafting.

In 1930, Charles Lindbergh, a famous aviator whose sisterin-law was suffering from rheumatic heart disease, approached Carrel. As the doctors of Lindbergh's sister-in-law had explained that surgery was not an option because the circulatory obstacles of heart surgery had not been overcome, Lindbergh asked Carrel to develop a mechanical pump that could help circulate blood during heart surgery. Working together, Carrel and Lindbergh developed a pump that enabled the maintenance of organs outside of the body for extended periods of time. Although surgically impractical during that period, the pump laid the foundation for future development in perfusion devices.

In his pursuit of organ transplantation, Carrel grew interested in tissue cultures, which he believed could offer a source for organ harvesting. He became the first person to grow tumour tissue in vitro. He also famously described keeping a culture of chick embryo heart cells alive for 34 years. However, skeptics have suggested that Carrel was unknowingly adding new cells to the culture through the addition of maintenance embryonic juices.

MILITARY SERVICE When World War I started, Carrel was drafted into the French military service, where he noted the high number of infected wounds. With the help of Henry Dakin, an English chemist from the Rockefeller Institute of Medicine, Carrel was able to find an antiseptic agent, sodium hypochlorite, that could destroy bacteria without severely irritating healthy tissue. Carrel perfected a method for delivering the agent, also known as Dakin's solution, at controlled rates to the affected site using a series of tubes inserted into the wound. This came to be known as the Carrel-Dakin method.

After Carrel was forced to retire from the Rockefeller Institute of Medicine at the age of 65 , and his petition for an age waiver rejected, Carrel returned to France, a country at war. In 1939, Carrel was again enlisted in the military when Adolf Hitler invaded Poland. Back in France, Carrel's attention turned to the construction of a mobile hospital. He was able to continue with this project when France surrendered to Germany in 1940. The Vichy regime, a new government installed by the Germans, established the Carrel Foundation for the Study of Human Problems. Through the Foundation, Carrel envisioned bringing philosophers, biologists, doctors, architects, economists and anthropologists together to solve the problems of humankind. Although he worked with the Vichy government to ensure funding, Carrel refused to accept any directorships or political appointments. However, when France was liberated in August of 1944, Carrel was immediately relieved of all research duties because of his collaboration with the Germans. Under government investigation and labelled a Nazi and a traitor by his compatriots, the heartbroken Carrel suffered a major heart attack and died at the age of 71 .

FALL FROM GRACE Carrel was not only a surgeon and scientist, but also a philosopher. Persuaded by friends, he published Man, the Unknown in 1935, a book about human physiology and medicine. The book also spoke of Carrel's belief in eugenics. A central idea throughout his career, Carrel advocated the establishment of a council of superior individuals to guide mankind. His controversial views included thoughts on women and criminals, stating that " $[w]$ omen should receive a higher education, not in order to become doctors, lawyers, or professors, but to rear their offspring to be valuable human beings," and that " $t]$ hose who have murdered, robbed while armed with an automatic pistol or machine gun, kidnapped children, despoiled the poor of their savings, misled the public in important manners, should be humanely and economically disposed of in small euthanasic institutions supplied with proper gases".

On the centennial of Carrel's birthday in 1973, France named numerous streets and buildings in various cities after him to commemorate his many accomplishments. However, in the 1990s, the National Front Party, an ultra-right wing political group, invoked Carrel's controversial views to justify its political position on restricting the rights of immigrants in France. A modern generation of French citizens, only vaguely familiar with Carrel's scientific accomplishments, began to examine his philosophical writings more closely, uncovering his views on eugenics. Carrel, France's native son and Nobel laureate, became a source of shame for the country. The public's disgust for Carrel was so great that the government removed Carrel's title from the streets and buildings that were once named in his honour, including the School of Medicine at the University of Lyons where the brilliant Nobel Prize winner underwent medical training.

\section{BIBLIOGRAPHY}

- Carrel A. Man, the Unknown. New York: Harper \& Brothers, 1935. Available at: http://www.soilandhealth.org/03sov/0303critic/030310ca rrel/Carrell-toc.htm. Accessed 15 June 2008.

- Durkin JT. Hope for Our Time: Alexis Carrel on Man and Society. New York: Harper \& Row, 1965.

- Edwards WS, Edwards PD. Alexis Carrel: Visionary Surgeon. Illinois: Charles C Thomas, 1974.

- McMurray EJ, Kosek JK, Valade RM. Notable Twentieth-century Scientists. Detroit: Gale Research, 1995. Available at: http://www.pbs.org/wnet/ redgold/innovators/bio_carrel.html. Accessed 15 June 2008.

- Nobel Lectures: Physiology or Medicine 1901-1921. Amsterdam: Elsevier, 1967. Available at: http://nobelprize.org/nobel_prizes/medicine/ laureates/1912/carrel-bio.html. Accessed 15 June 2008.

- Sade RM. Transplantation at 100 years: Alexis Carrel, pioneer surgeon. Ann Thorac Surg 2005; 80:2415-8.

- Weksler ME. Naming streets for physicians: "I'affaire Carrel". Perspect Biol Med 2004; 47:67-73.

- Witkowski JA. Dr. Carrel's immortal cells. Med Hist 1980; 24:129-42. 